\title{
Comparison of the effects of oviductal cell co-culture and oviductal cell-conditioned medium on the development and metabolic activity of cattle embryos
}

\author{
D. Rieger ${ }^{\mathrm{I}}$, B. Grisart ${ }^{2}$, E. Semple ${ }^{1}$, A. Van Langendonckt ${ }^{2}$, \\ K. J. Betteridge ${ }^{1}$ and F. Dessy ${ }^{2}$ \\ ${ }^{1}$ Department of Biomedical Sciences, University of Guelph, Guelph, Ontario, Canada, N1G 2W1; and \\ ${ }^{2}$ Unité des Sciences Vétérinaires, Place Croix du Sud 3, Université catholique de Louvain, \\ B-1348 Louvain-la-Neuve, Belgium
}

\begin{abstract}
The objective of this study was to compare the development and metabolic activity of cattle embryos co-cultured with bovine oviductal cells or cultured in serum-free medium previously conditioned by bovine oviductal cells. Zygotes were produced by in vitro fertilization of oocytes from bovine ovaries obtained from an abattoir. Development to the four-cell stage occurred by $48 \mathrm{~h}$ after fertilization in both culture systems, but co-cultured embryos reached the 16-cell stage by $96 \mathrm{~h}$, whereas those cultured in conditioned medium did not do so until $24 \mathrm{~h}$ later. Similarly, the morula and blastocyst stages were reached $24 \mathrm{~h}$ earlier in co-culture than in conditioned medium. There were significantly more cells in the blastocysts from co-culture $(96.8 \pm 6.1$ versus $56.7 \pm 3.3 ; P \leq 0.0001)$. The metabolism of glutamine did not differ between embryos cultured in the two systems, but the metabolism of glucose was significantly greater in embryos cultured in conditioned medium. The first significant increase in glucose metabolism occurred between the four-cell and the 16-cell stages in embryos cultured in conditioned medium, but occurred between the 16-cell and morula stages in the co-cultured embryos, such that the glucose metabolism was significantly greater at the 16-cell stage in embryos cultured in conditioned medium compared with co-cultured embryos $(6.5 \pm 1.0$ versus $1.5 \pm 0.4$ pmol per embryo per $3 \mathrm{~h}$, $P \leq 0.0001$ ). The concentration of glucose was significantly less, and that of lactate significantly greater, in co-culture medium than in conditioned medium. The results suggest that the activity of enzymes involved in glucose transport or metabolism in the early cattle embryo can be affected by the prior culture conditions, and that a high rate of glucose metabolism may be unfavourable for development.
\end{abstract}

\section{Introduction}

In general, the development of cattle embryos is arrested or blocked between the eight-cell and 16-cell stages when they are cultured in conventional complex cell-culture media (reviewed by Thibault, 1966; First and Parrish, 1987; Greve and Madison, 1991). Co-culture with oviductal cells, or culture in oviductal cell-conditioned medium, can support the development of sheep (Gandolfi and Moor, 1987; Rexroad and Powell, 1988) and cattle (Fukui and Ono, 1988; Eyestone and First, 1989; Ellington et al., 1990; Gordon and Lu, 1990; Mermillod et al., 1992a) embryos through the block.

We have shown that cattle embryos produced by in vitro maturation and fertilization of oocytes collected from ovaries obtained from an abattoir develop to the blastocyst stage, expand, and hatch in culture, and produce pregnancies and live calves after transfer to recipient cows after either co-culture

Manuscript received 17 February 1995 with bovine oviductal cells (Xu et al., 1992a, b), or culture in medium that has been conditioned with bovine oviductal cells (Mermillod et al., 1992a, b). Calves have also been produced from such embryos after micromanipulation (Loskutoff et al., 1993; Johnson et al., 1995) and cryopreservation (Massip et al., 1993; J. W. Pollard and S. P. Leibo, personal communication).

However, there is a significant difference in the timing of development in the two culture systems. Development to the four-cell stage occurs at $40-48 \mathrm{~h}$ after in vitro fertilization in both co-culture and in conditioned medium, whereas development to the 16-cell stage occurs by, on average, $90 \mathrm{~h}$ in co-culture (Rieger et al., 1992a), but it does not occur until $120 \mathrm{~h}$ in conditioned medium, owing to an extended period at the 5-8-cell stage (Grisart et al., 1994). This delay in development in conditioned medium is of interest because it is intermediate between the total arrest seen in conventional complex cell-culture media and the fast development seen in co-culture. It therefore offers a model to investigate the mechanism(s) by which somatic cells support the development Downloaded from Bioscientifica.com at 04/26/2023 11:10:05AM 
of embryos in vitro. The difference in timing of development is also of interest because there is a significant change in the patterns of energy metabolism of co-cultured cattle embryos between the four-cell and blastocyst stages (Rieger et al, 1992a, b).

The objective of the present experiments was to compare directly the effects of co-culture and culture in conditioned medium on the development of cattle embryos, and to determine whether the differences in development were accompanied by differences in metabolic activity. The production of ${ }^{3} \mathrm{H}_{2} \mathrm{O}$ from D- $\left[5-{ }^{3} \mathrm{H}\right]$ glucose was used as a measure of total anaerobic glucose metabolism (to phosphoenolpyruvate), and the production of ${ }^{14} \mathrm{CO}_{2}$ from $\mathrm{L}-\left[{ }^{14} \mathrm{C}(\mathrm{U})\right]$ glutamine by the Krebs cycle was used as a measure of mitochondrial oxidative metabolism (Rieger and Guay, 1988; Rieger et al., 1992a, b).

\section{Materials and Methods}

\section{Culture reagents}

Fetal calf serum (FCS), TCM-199, penicillin and streptomycin were obtained from Gibco BRL (Paisley). Porcine FSH $(\mathrm{pFSH})$ and $\mathrm{LH}(\mathrm{pLH})$ were kindly provided by J. F. Beckers, Liège. Heat-treated donor steer serum was purchased from Cansera, Inc., (Rexdale, Ontario), paraffin oil from Merck (Darmstadt), and silicone oil from Dow Corning (Midland, MI). Unless otherwise indicated, all other culture reagents were "cell culture tested" reagents from Sigma (St Louis, MO).

\section{Oocyte collection, in vitro maturation and in vitro fertilization}

The experiments were conducted in Louvain-la-Neuve. Four separate batches of oocyte-cumulus complexes $(n=369,218$, 258 and 268) were matured and fertilized in vitro using methods slightly modified from those described by Mermillod et al. (1993). Oocyte-cumulus complexes were collected by aspiration of 2-5 $\mathrm{mm}$ follicles from cow ovaries obtained from an abattoir, and washed three times in modified Dulbecco's PBS containing $3.3 \mathrm{mmol}$ pyruvate $\mathrm{l}^{-1}$ and $4 \mathrm{mg}$ fraction $\mathrm{V}$ BSA $\mathrm{ml}^{-1}$ (Buffer A). Groups of 100 oocyte-cumulus complexes were matured in $500 \mu \mathrm{l}$ maturation medium (TCM-199 containing $10 \%(\mathrm{v} / \mathrm{v})$ fetal calf serum, I $\mu \mathrm{g}$ oestradiol $\mathrm{ml}^{-1}, 5 \mu \mathrm{g}$ $\mathrm{pLH} \mathrm{ml}^{-1}$ and $0.5 \mu \mathrm{g} \mathrm{pFSH} \mathrm{ml}{ }^{-1}$ ). After maturation for $24 \mathrm{~h}$ at $39^{\circ} \mathrm{C}$ in an humidified atmosphere of $5 \% \mathrm{CO}_{2}$ in air, the oocytes were washed three times in Buffer $\mathrm{A}$ and transferred into $500 \mu \mathrm{l}$ fertilization medium (Tyrode's medium containing albumin, lactate and pyruvate (TALP) supplemented with $10 \mu \mathrm{g}$ heparin $\mathrm{ml}^{-1}$ ).

Spermatozoa were selected by centrifugation of thawed semen on a Percoll discontinuous density gradient $(45 / 90 \%)$ for $30 \mathrm{~min}$ at $700 \mathrm{~g}$. After a second centrifugation in TALP to remove any traces of Percoll, the living spermatozoa were added to the fertilization well to obtain a final concentration of $2 \times 10^{6} \mathrm{ml}^{-1}$. After fertilization for $18 \mathrm{~h}$ at $39^{\circ} \mathrm{C}$, the presumptive zygotes were stripped of cumulus cells by vortexing for 2 min, and washed twice in Buffer A and twice in culture medium.

Approximately equal numbers of the presumptive zygotes (all the oocytes, without selection) were then assigned randomly to two culture treatment groups: co-culture with bovine oviductal epithelial cells, or culture in medium conditioned by bovine oviductal epithelial cells.

\section{Embryo co-culture with bovine oviductal epithelial cells}

The medium used for co-culture was TCM-199 supplemented with $60000 \mathrm{iu}$ penicillin $\mathrm{I}^{-\mathrm{I}}$ and $60 \mathrm{mg}$ streptomycin $\mathrm{I}^{-1}$, and with $5 \mathrm{mmol}$ sodium pyruvate $\mathrm{l}^{-1}$ and 2 mmol L-glutamine $\mathrm{I}^{-1}$. Osmolality was adjusted to 280 mosm $~^{-1}$ with sterile distilled water before addition of $10 \%(\mathrm{v} / \mathrm{v})$ heat-treated donor steer serum and $3.5 \mathrm{~g} \mathrm{BSA} \mathrm{I}^{-1}$ (Fraction V).

On the same day as oocyte collection, an oviduct was processed to produce oviductal cell cylinders as described by Xu et al. (1992b). On the next day, groups of 40-50 oviductal cell cylinders were placed in $50 \mu \mathrm{l}$ drops of co-culture medium under silicone oil (Dow Corning, Midland, MI) and cultured at $39^{\circ} \mathrm{C}$ in an atmosphere of $5 \% \mathrm{CO}_{2}$ in air for $24 \mathrm{~h}$. Groups of 30 presumptive zygotes were then added to each culture drop (at $18 \mathrm{~h}$ after insemination) and cultured for up to 7 days. At $48 \mathrm{~h}$ after the zygotes were introduced, each co-culture drop was supplemented with $25 \mu \mathrm{l}$ serum-free co-culture medium. At $120 \mathrm{~h}$, each co-culture drop was supplemented with $25 \mu \mathrm{l}$ serum-replete co-culture medium.

\section{Embryo culture in serum-free medium conditioned by bovine oviductal epithelial cells}

Cow oviducts were randomly obtained from an abattoir. Bovine oviductal epithelial cells were isolated and cultured to produce monolayers, as described by Eyestone and First (1989). Embryo culture medium was conditioned by these monolayers under serum-free conditions and harvested and stored until required according to the procedure detailed by Mermillod et al. (1993). At $18 \mathrm{~h}$ after insemination, groups of 40 presumptive zygotes were placed in $40 \mu \mathrm{l}$ drops of conditioned medium under paraffin oil and cultured at $39^{\circ} \mathrm{C}$ in a humidified atmosphere of $5 \% \mathrm{CO}_{2}$ in air, for up to 8 days.

\section{Metabolic measurements}

The medium used for the metabolic measurements was a modified synthetic oviductal fluid (Tervit et al., 1972) containing $108 \mathrm{mmol} \mathrm{NaCl} \mathrm{I}{ }^{-1}, 25 \mathrm{mmol} \mathrm{NaHCO}_{3} \mathrm{l}^{-1}, 7.2 \mathrm{mmol}$ $\mathrm{KCl} 1^{-1}, 1.7 \mathrm{mmol} \mathrm{CaCl}_{2} 1^{-1}, 1.2 \mathrm{mmol} \mathrm{KH}_{2} \mathrm{PO}_{4} 1^{-1}$, $0.5 \mathrm{mmol} \mathrm{MgCl} \mathrm{I}^{-1}, 1.0 \mathrm{mmol}$ glucose $\mathrm{l}^{-1}, 1.0 \mathrm{mmol}$ pyruvate $\mathrm{I}^{-\mathrm{I}}, 1.5 \mathrm{mmol}$ L-glutamine $\mathrm{I}^{-1}, 3.5 \mathrm{~g}$ essential fatty acid-free bovine serum albumin $1^{-1}, 100000$ iu penicillin $l^{-1}$, $100 \mathrm{mg}$ streptomycin $\mathrm{l}^{-1}$, and $20 \mathrm{mmol}$ Hepes $\mathrm{l}^{-1}$.

Groups of 8-12 embryos at the four-cell, nominal 16-cell, compacted morula, and blastocyst stages were removed from co-culture at $48,96,144$ and $168 \mathrm{~h}$ after insemination, and from conditioned medium culture at $48,120,168$ and $192 \mathrm{~h}$ after insemination, respectively. Each of the four developmental stages was derived from a separate batch of oocytes. At each stage, the co-cultured embryos and those cultured in conditioned medium were derived from the same batch of oocytes. The embryos were washed four times and cultured for Downloaded from Bioscientifica.com at 04/26/2023 11:10:05AM 
$4 \mathrm{~h}$ in metabolic measurement medium at $39^{\circ} \mathrm{C}$ in a humidified atmosphere of $5 \% \mathrm{CO}_{2}$ in air before being subjected to the metabolic measurement procedure.

Except for the medium, the procedure used to measure embryo metabolism was exactly as described by Rieger et al. (1992a). A mixture of $\mathbf{L}-\left[\mathrm{U}-{ }^{14} \mathrm{C}\right]$ glutamine (specific activity $=262 \mathrm{mCi} \mathrm{mmol}^{-1}$, NEN, Dupont, Wilmington, DE) and $\mathrm{D}-\left[5-{ }^{3} \mathrm{H}\right]$ glucose (specific activity $=15.7 \mathrm{Ci} \mathrm{mmol}{ }^{-1}$, Amersham, Little Chalfont) was dried under nitrogen and taken up in metabolic measurement medium to give nominal concentrations of $0.25 \mu \mathrm{Ci} \mu \mathrm{l}^{-1}$ for each labelled substrate. The final concentrations (labelled plus unlabelled) were $2.0 \mathrm{mmol} \mathrm{l}^{-1}$ and $1.0 \mathrm{mmol} \mathrm{I^{-1 }}$ for glutamine and glucose, respectively. The amount of glutamine and glucose metabolized by each embryo was calculated as described by Tiffin et al. (1991). The sensitivities of the assays were $0.6 \mathrm{pmol}$ per $3 \mathrm{~h}$ for glutamine, and 0.1 pmol per $3 \mathrm{~h}$ for glucose.

\section{Cell counting}

Immediately after the metabolic measurement procedure, the embryos were fixed with $70 \%(\mathrm{v} / \mathrm{v})$ ethanol using the procedure described by Mermillod et al. (1993). After ethanol fixation, their nuclei were stained using Hoechst-33342 dye as described by Pursel et al. (1985) and counted under an epifluorescence microscope (Nikon, Optiphot) equipped with an excitation filter of $330-380 \mathrm{~nm}$ and a barrier filter of $420 \mathrm{~nm}$.

\section{Measurement of glucose and lactate concentrations in co-culture medium and in conditioned medium}

In a separate experiment, $50 \mu \mathrm{l}$ drops containing bovine oviductal epithelial cells were prepared and cultured for 7 days, as described above for co-culture, but without embryos. Time 0 was defined as the time when embryos were introduced into the culture drops. In two trials, samples of medium were taken at $-24,0,24,48,120$ and $144 \mathrm{~h}$. At 48 and $120 \mathrm{~h}$, samples were taken immediately before, and immediately after, the supplementation with fresh medium. Samples were also taken from six batches of conditioned medium that were prepared as described above.

The glucose concentrations in $100 \mu \mathrm{l}$ aliquots of the media samples were determined by spectrophotometric measurement of the reduction of nicotinamide adenine dinucleotide by a hexokinase-glucose-6-phosphate dehydrogenase-coupled reaction (Coulter glucose reagent, Coulter Electronics, Burlington, Ontario).

The lactate concentrations in $10 \mu \mathrm{l}$ aliquots of the media samples were determined by colorimetric measurement of the red peroxidation product of 4-aminoantipyrine and 1,7-dihydroxynaphthalene formed by a lactate oxidasehorseradish peroxidase coupled reaction (Kodak Ektachem DT Slide (LAC), Kodak Clinical Products, Rochester, NY).

\section{Statistical analysis}

The numbers of cells at the nominally 16-cell, morula and blastocyst stages produced in co-culture and conditioned medium were compared by orthogonal contrasts. All other data were $\log$-transformed, where $y^{\prime}=\log (y+1)$, to provide homogeneity of variance for statistical analysis using SuperANOVA (Abacus Concepts Inc., Berkeley, CA). The effects of culture treatment and stage of development on the measurements of metabolism were evaluated by two-way analyses of variance. For analyses with significant effects of stage of development and treatment $x$ stage interaction, the means of successive stages within each treatment, and means of the same stage between treatments, were compared by orthogonal contrasts. For analyses with a significant effect of stage of development, but no effect of treatment $x$ stage interaction, the pooled means of successive stages were compared by orthogonal contrasts. The effect of time on the concentrations of glucose and lactate in co-culture medium was evaluated by one-way analysis of variance for repeated measures. Mean concentrations in successive samples were compared by orthogonal contrasts.

\section{Results}

\section{Comparison of embryo development in co-culture and in} conditioned medium

The embryos reached the four-cell stage by $48 \mathrm{~h}$ after insemination in both co-culture and in conditioned medium (Table 1). One nominally 16-cell conditioned-medium embryo was lost after the metabolic measurement, and the numbers of cells in three conditioned-medium blastocysts could not be determined. The actual numbers of cells at the nominal 16-cell stage ranged from 11 to 19 in the co-cultured embryos and from 13 to 28 in the embryos cultured in conditioned medium, but the means were not different $(P>0.05)$. However, whereas the embryos in co-culture reached the 16-cell stage by $96 \mathrm{~h}$, those cultured in conditioned medium did not do so until $120 \mathrm{~h}, 24 \mathrm{~h}$ later. Similarly, the morula and blastocyst stages were reached $24 \mathrm{~h}$ earlier in co-culture than in conditioned medium. The number of cells in the morulae produced in the two systems did not differ $(P>0.05)$. However, at the blastocyst stage, there were significantly more cells in the embryos from co-culture $(P \leq 0.0001)$.

\section{Comparison of glucose and glutamine metabolism by embryos co-cultured with oviductal cells or cultured in conditioned medium}

Overall, the embryos cultured in conditioned medium metabolized significantly more glucose than did the co-cultured embryos $(P \leq 0.0001)$. There were also highly significant effects of stage of development $(P \leq 0.0001)$, and treatment $x$ stage interaction $(P \leq 0.01)$ on glucose metabolism (Table 2). For the co-cultured embryos, the first significant increase in glucose metabolism occurred between the 16-cell and morula stages, whilst the first significant increase occurred between the four-cell and 16-cell stages in the embryos cultured in conditioned medium. Glucose metabolism at the 16-cell stage was significantly greater in embryos cultured in conditioned medium than in co-cultured embryos. 
Table 1. The times of recovery and numbers of cells in cattle embryos co-cultured with bovine oviductal epithelial cells or in conditioned medium

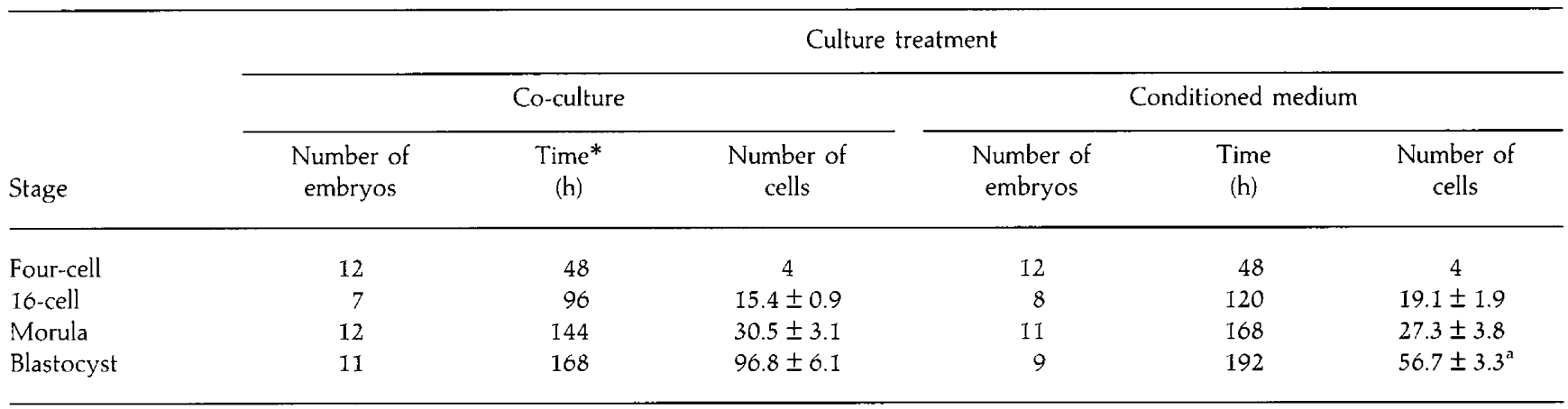

*Time after insemination.

Numbers of cells are means \pm SEM.

aSignificantly different from the same stage in the co-culture group $(P \leq 0.0001)$.

Table 2. The effect of co-culture with bovine oviductal epithelial cells or culture in conditioned medium, and stage of development, on the metabolism of glucose by cattle embryos

\begin{tabular}{|c|c|c|c|c|c|c|}
\hline \multirow[b]{3}{*}{ Stage } & \multicolumn{6}{|c|}{ Culture treatment } \\
\hline & \multicolumn{2}{|c|}{ Co-culture } & \multicolumn{2}{|c|}{ Conditioned medium } & \multicolumn{2}{|c|}{ Pooled } \\
\hline & $\begin{array}{c}\text { Number of } \\
\text { embryos }\end{array}$ & $\begin{array}{l}\text { Metabolism } \\
\text { (pmol per } \\
\text { embryo per } 3 \mathrm{~h} \text { ) }\end{array}$ & $\begin{array}{c}\text { Number of } \\
\text { embryos }\end{array}$ & $\begin{array}{c}\text { Metabolism } \\
\text { (pmol per } \\
\text { embryo per } 3 \mathrm{~h} \text { ) }\end{array}$ & $\begin{array}{c}\text { Number of } \\
\text { embryos }\end{array}$ & $\begin{array}{c}\text { Metabolism } \\
\text { (pmol per } \\
\text { embryo per } 3 \mathrm{~h} \text { ) }\end{array}$ \\
\hline Four-cell & 12 & $0.7 \pm 0.1$ & 12 & $1.5 \pm 0.6$ & 24 & $1.1 \pm 0.3$ \\
\hline 16 -cell & 7 & $1.5 \pm 0.4$ & 9 & $6.5 \pm 1.0^{\mathrm{ab}}$ & 16 & $4.4 \pm 0.9$ \\
\hline Morula & 12 & $17.7 \pm 2.5^{\mathrm{a}}$ & 11 & $22.4 \pm 3.1^{\mathrm{a}}$ & 23 & $19.9 \pm 2.0$ \\
\hline Blastocyst & 11 & $35.0 \pm 2.9^{\mathrm{a}}$ & 12 & $44.8 \pm 5.0^{a}$ & 23 & $40.1 \pm 3.1$ \\
\hline
\end{tabular}

Metabolism values are means \pm SEM.

aSignificantly different from the preceding stage in the same column ( $P \leq 0.0002$ ).

bignificantly different from the same stage in the co-culture group $(P \leq 0.0001)$.

The embryos cultured in conditioned medium also metabolized significantly more glucose per cell than did the co-cultured embryos $(P \leq 0.0001)$. There was a highly significant effect of stage of development $(P \leq 0.0001)$ on glucose metabolism per cell, but no effect of treatment $x$ stage interaction (Table 3). For the pooled data, there was a highly significant increase between the 16-cell and morula stages, but no difference between the four-cell and 16-cell stages, or between the morula and blastocyst stages.

There was a highly significant effect of stage of development $(P \leq 0.0001)$ on glutamine metabolism but no significant effect of culture treatment or interaction (Table 4). For the pooled data, glutamine metabolism tended to decrease from the four-cell to 16-cell stage ( $P \leq 0.06$ ), and increased significantly $(P \leq 0.05)$ between the 16-cell and morula stages and between the morula and blastocyst stages.

There was a highly significant effect of stage of development on glutamine metabolism per cell $(P \leq 0.0001)$, but no effect of culture treatment or interaction (Table 5). For the pooled data, there was a highly significant decrease in glutamine metabolism per cell between the four-cell and 16-cell stages, but no change thereafter.
There were highly significant effects of culture treatment and stage of development $(P \leq 0.0001)$, and of treatment $\times$ stage interaction $(P \leq 0.005)$ on the ratio of glucose metabolism to glutamine metabolism (Table 6). In the co-cultured embryos, the metabolism ratio increased significantly between the 16-cell and morula stages, but was not different between the four-cell and 16-cell stages, nor between the morula and blastocyst stages. In the embryos cultured in conditioned medium, the ratio increased significantly between the four-cell and 16-cell stages, and again between the 16-cell and morula stages, but was unchanged between the morula and blastocyst stages. At the 16-cell stage, the ratio was significantly greater in the embryos cultured in conditioned medium than in the co-cultured embryos.

Glucose and lactate concentrations in co-culture medium and in conditioned medium

There was a significant effect of culture time on the concentrations of both glucose $(P \leq 0.0002)$ and lactate $(P \leq 0.0001)$ in the bovine oviductal epithelial cell co-culture Downloaded from Bioscientifica.com at 04/26/2023 11:10:05AM 
Table 3. The effect of co-culture with bovine oviductal epithelial cells or culture in conditioned medium, and stage of development, on glucose metabolism per cell by cattle embryos

\begin{tabular}{|c|c|c|c|c|c|c|}
\hline \multirow{2}{*}{ Stage } & \multicolumn{6}{|c|}{ Culture treatment } \\
\hline & \multicolumn{2}{|c|}{ Co-culture } & \multicolumn{2}{|c|}{ Conditioned medium } & \multicolumn{2}{|c|}{ Pooled } \\
\hline 16-cell & 7 & $0.1 \pm 0.0$ & 8 & $0.4 \pm 0.0$ & 15 & $0.2 \pm 0.0$ \\
\hline Morula & 12 & $0.6 \pm 0.1$ & 11 & $0.9 \pm 0.1$ & 23 & $0.7 \pm 0.1^{\mathrm{a}}$ \\
\hline Blastocyst & 11 & $0.4 \pm 0.0$ & 9 & $0.8 \pm 0.1$ & 20 & $0.6 \pm 0.1$ \\
\hline
\end{tabular}

Metabolism values are means \pm SEM.

${ }^{2}$ Significantly different from the preceding mean in the same column $(P \leq 0.0001)$.

Table 4. The effect of co-culture with bovine oviductal epithelial cells or culture in conditioned medium, and stage of development, on the metabolism of glutamine by cattle embryos

Culture treatment

\begin{tabular}{|c|c|c|c|c|c|c|}
\hline \multicolumn{2}{|c|}{ Co-culture } & & \multicolumn{2}{|c|}{ Conditioned medium } & \multicolumn{2}{|c|}{ Pooled } \\
\hline Four-cell & & $3.3 \pm 0.5$ & 12 & $4.3 \pm 0.8$ & 24 & $3.8 \pm 0.5$ \\
\hline 16-cell & & $2.4 \pm 0.5$ & 9 & $2.7 \pm 0.5$ & 16 & $2.6 \pm 0.4$ \\
\hline
\end{tabular}

Metabolism values are means \pm SEM.

a'Significantly different from the preceding stage in the same column $(P \leq 0.05)$.

medium (Fig. 1). Glucose fell from $5.8 \mathrm{mmol} \mathrm{l}^{-1}$, when the epithelial cells were placed in the droplets at $-24 \mathrm{~h}$, to $0.6 \mathrm{mmol} \mathrm{l}^{-1} 24 \mathrm{~h}$ later, when embryos normally would be introduced (time 0). Glucose concentration remained low until $144 \mathrm{~h}$, rising briefly after the drops were supplemented with fresh medium at 48 and $120 \mathrm{~h}$. The pattern for lactate was exactly opposite to that of glucose, increasing from $1.2 \mathrm{mmol}$ $\mathrm{l}^{-1}$ at $-24 \mathrm{~h}$ to $7.2 \mathrm{mmol} \mathrm{l}^{-1}$ at $0 \mathrm{~h}$, and $9.5 \mathrm{mmol} \mathrm{l}^{-1}$ at $24 \mathrm{~h}$. Lactate concentration decreased temporarily when the drops were supplemented with fresh medium, but the changes were not statistically significant. The mean concentrations ( \pm SEM) of glucose and lactate in the bovine oviductal epithelial cell conditioned media were $1.7 \pm 0.4 \mathrm{mmol} \mathrm{l}^{-1}$ and $3.1 \pm 0.6 \mathrm{mmol} \mathrm{l}^{-1}$, respectively. Except at $-24 \mathrm{~h}$, and immediately after supplementation with fresh medium, the concentration of glucose in the co-culture droplets was below the lower $95 \%$ confidence limit for glucose concentration in the conditioned medium $\left(0.9 \mathrm{mmol}^{-1}\right)$. Except at $-24 \mathrm{~h}$, the concentration of lactate in the co-culture droplets was above the upper $95 \%$ confidence limit for lactate concentration in the conditioned medium $\left(4.1 \mathrm{mmol} \mathrm{l^{-1 }}\right)$ during the entire co-culture period.

\section{Discussion}

The timing of development of the cattle embryos in this study was consistent with our observations that development to the 16-cell, morula and blastocyst stages is delayed by $24 \mathrm{~h}$ in conditioned medium (Grisart ef al., 1994) compared with that in oviductal cell co-culture (Rieger et al., 1992a). Moreover, the mean number of cells in blastocysts produced by culture in conditioned medium was significantly lower than in blastocysts produced by co-culture $(56.7 \pm 3.3$ versus $96.8 \pm 6.1$; $P \leq 0.0001$ ), even though the blastocysts produced by culture in conditioned medium were $24 \mathrm{~h}$ older. This finding agrees closely with the observations of Trounson et al. (1994), who observed that the mean number of cells is significantly greater in blastocysts produced by bovine oviductal cell co-culture than in those cultured in conditioned medium.

The lower number of cells in the blastocysts produced by culture in conditioned medium suggests that the delay in development between the four-cell and 16-cell stages is associated with a decrease in subsequent developmental potential of the embryo. Yadav et al. (1993) showed that cattle embryos that are late in undergoing the first cleavage division 
Table 5. The effect of co-culture with bovine oviductal epithelial cells or culture in conditioned medium, and stage of development on the metabolism per cell of glutamine by cattle embryos

Culture treatment

\begin{tabular}{|c|c|c|c|c|c|c|}
\hline \multirow[b]{2}{*}{ Stage } & \multicolumn{2}{|c|}{ Co-culture } & \multicolumn{2}{|c|}{ Conditioned medium } & \multicolumn{2}{|c|}{ Pooled } \\
\hline & $\begin{array}{c}\text { Number of } \\
\text { embryos }\end{array}$ & $\begin{array}{l}\text { Metabolism } \\
\text { (pmol per } \\
\text { cell per } 3 \mathrm{~h} \text { ) }\end{array}$ & $\begin{array}{c}\text { Number of } \\
\text { embryos }\end{array}$ & $\begin{array}{l}\text { Metabolism } \\
\text { (pmol per } \\
\text { cell per } 3 \mathrm{~h} \text { ) }\end{array}$ & $\begin{array}{c}\text { Number of } \\
\text { embryos }\end{array}$ & $\begin{array}{l}\text { Metabolism } \\
\text { (pmol per } \\
\text { cell per } 3 \mathrm{~h} \text { ) }\end{array}$ \\
\hline Four-cell & 12 & $0.8 \pm 0.1$ & 12 & $1.1 \pm 0.2$ & 24 & $0.9 \pm 0.1$ \\
\hline Blastocyst & 11 & $0.1 \pm 0.0$ & 9 & $0.1 \pm 0.0$ & 20 & $0.1 \pm 0.0$ \\
\hline
\end{tabular}

Metabolism values are means \pm SEM.

${ }^{a}$ Significantly different from the preceding stage in the same column $(P \leq 0.001)$.

Table 6. The effect of co-culture with bovine oviductal epithelial cells or culture in conditioned medium, and stage of development, on the ratio of glucose to glutamine metabolism by cattle embryos

\begin{tabular}{|c|c|c|c|c|c|c|}
\hline \multirow[b]{3}{*}{ Stage } & \multicolumn{6}{|c|}{ Culture treatment } \\
\hline & \multicolumn{2}{|c|}{ Co-culture } & \multicolumn{2}{|c|}{ Conditioned medium } & \multicolumn{2}{|c|}{ Pooled } \\
\hline & $\begin{array}{c}\text { Number of } \\
\text { embryos }\end{array}$ & $\begin{array}{l}\text { Metabolism } \\
\text { ratio }\end{array}$ & $\begin{array}{c}\text { Number of } \\
\text { embryos }\end{array}$ & $\begin{array}{c}\text { Metabolism } \\
\text { ratio }\end{array}$ & $\begin{array}{c}\text { Number of } \\
\text { embryos }\end{array}$ & $\begin{array}{c}\text { Metabolism } \\
\text { ratio }\end{array}$ \\
\hline Four-cell & 12 & $0.3 \pm 0.1$ & 12 & $0.4 \pm 0.2$ & 24 & $0.4 \pm 0.1$ \\
\hline 16-cell & 7 & $0.6 \pm 0.0$ & 9 & $3.3 \pm 0.9^{\mathrm{ab}}$ & 16 & $2.1 \pm 0.6$ \\
\hline Morula & 12 & $4.7 \pm 0.4^{\mathrm{a}}$ & 11 & $6.2 \pm 0.9^{\mathrm{a}}$ & 23 & $5.4 \pm 0.5$ \\
\hline Blastocyst & 11 & $5.3 \pm 0.7$ & 12 & $6.9 \pm 0.7$ & 23 & $6.1 \pm 0.5$ \\
\hline
\end{tabular}

Metabolism ratios are means \pm SEM.

${ }^{a}$ Significantly different from the preceding mean in the same column ( $\left.P \leq 0.0005\right)$.

'Significantly different from the same stage in the co-culture group ( $P \leq 0.0001$ ).

have a reduced number of cells at the blastocyst stage. Cattle embryos that are late in reaching the blastocyst stage are less likely to hatch in vitro or develop after transfer to recipient cows (Massip et al., 1995; J. W. Pollard and S. P. Leibo, personal communication).

The mechanism by which oviductal cells or other somatic cells can improve the development of early mammalian embryos in vitro is unknown. Early embryos have receptors for a variety of cellular growth factors (Schultz and Heyner, 1993), and it has been suggested that somatic cells may secrete tissue-specific or non-specific growth factors that can stimulate embryo development (reviewed by Gandolfi, 1994). However, there is no direct evidence for this, and it has therefore been suggested that somatic cells simply remove deleterious substances, notably glucose, from the medium (reviewed by Bavister, 1992; Bavister, 1995). This view is supported by the observations that embryos develop better in simple glucosefree media such as CZB (Chatot et al., 1989), HECM (McKiernan et al., 1991), CR2 (Rosenkrans et al., 1993), and KSOM (Erbach et al., 1994) than in complex glucose-containing media. It is therefore interesting that the oviductal cell cylinders used in the co-culture reduced the glucose concentration in TCM-199 more than did conditioning on oviductal cell monolayers. The more rapid development and greater number of cells in blastocysts of embryos in co-culture compared with those cultured in conditioned medium is consistent with the observation that the development of sheep embryos is impaired by glucose concentrations greater than $1.5 \mathrm{mmol}^{-1}$ (Thompson et al., 1992).

The higher lactate concentration in the co-culture droplets compared with the conditioned medium may also have contributed to the relatively better embryo development in co-culture. Lactate can be used as an energy substrate by mouse and hamster embryos, and may also serve to maintain the proper redox balance and intracellular $\mathrm{pH}$ (reviewed by Leese, 1991; Bavister, 1995). Our results are consistent with the observations that lactate concentrations of $3.3-10 \mathrm{mmol} \mathrm{l}^{-1}$ favour the development of sheep (Thompson et al., 1993) and cattle embryos (Takahashi and First, 1992; Rosenkrans et al., 1993).

The results also suggest that the culture conditions can affect the ability of the embryo to metabolize glucose. For the Downloaded from Bioscientifica.com at 04/26/2023 11:10:05AM 


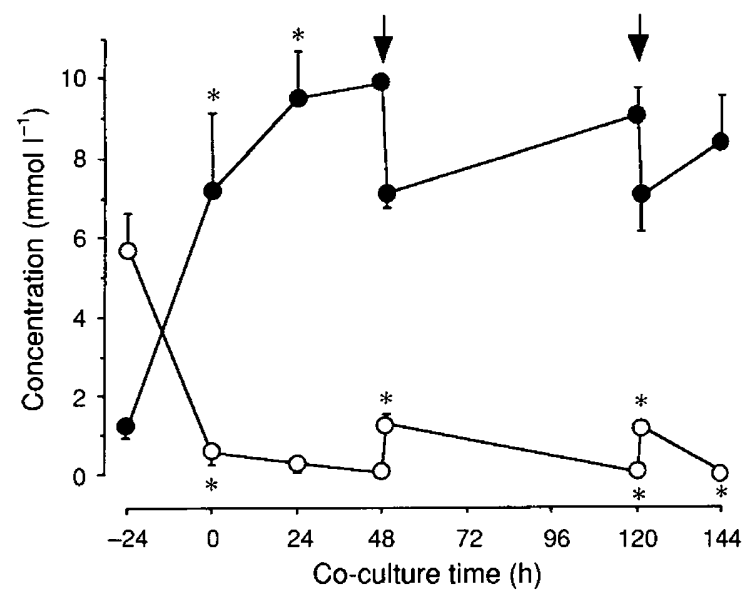

Fig. 1. The effect of time on the mean concentrations ( \pm SEM) of glucose (O) and lactate ( $)$ in bovine oviductal epithelial cell co-culture droplets. Embryos are normally introduced at time 0 . The arrows indicate the times when the co-culture droplets were supplemented with fresh medium. *Significantly different from the preceding sample mean for the same substrate $(P \leq 0.05)$.

co-cultured embryos, glucose metabolism was low at the four-cell and 16-cell stages and then increased significantly through the morula and blastocyst stages, which is consistent with previous observations (Rieger et al., 1992a, b). However, the pattern of glucose metabolism by the embryos cultured in conditioned medium was significantly different, in that embryos metabolized significantly more glucose overall than did those in co-culture, on both a per embryo, and a per cell, basis. In particular, glucose metabolism increased significantly between the four-cell and 16-cell stages in the embryos cultured in conditioned medium, whereas there was no significant change in the co-cultured embryos. Consequently, the metabolism of glucose at the 16-cell stage was four times greater by embryos cultured in conditioned medium than by co-cultured embryos. There is a large increase in glucose uptake between the eight-cell and 16-cell stages in cattle embryos produced by co-culture, and consequently the proportion of glucose metabolized by those embryos is at a minimum at the 16-cell stage (Rieger et al., 1992b). It is not yet clear whether the embryos cultured in conditioned medium took up more glucose than did the co-cultured embryos, or metabolized a larger proportion of the glucose that they absorbed.

The metabolism of glucose was directly related to the glucose concentration in the culture medium; glucose concentration was higher in the conditioned medium and glucose metabolism was higher in embryos cultured in the conditioned medium. This may suggest that the enzymes involved in glucose transport or metabolism in the early cattle embryo can be induced or activated in response to high glucose or low lactate concentrations in the culture medium. However, whereas the conditioned medium was serum-free, the coculture medium contained $10 \%$ serum, which may have had a more direct and unknown effect on glucose metabolism by the embryos. In addition, it seems likely that the actively metabolizing oviductal cells would significantly reduce the oxygen concentration, which could also affect the glycolytic enzymes. Whatever the mechanism, it is clear that glucose metabolism by the embryos was affected by the prior culture conditions. To the best of our knowledge, this is a novel observation for embryos of any species.

In contrast to the significant difference in the patterns of glucose metabolism, there were no significant differences in the patterns of glutamine metabolism between the embryos cultured in the two systems. There was, therefore, no apparent relationship between oxidative metabolism and the numbers of cells at the blastocyst stage. Glutamine metabolism is increased by cryopreservation treatments in both horse (Rieger et al., 1991) and cattle (Rieger et al, 1993) blastocysts, possibly a result of disturbances in mitochondrial function. However, the present results provide no evidence to suggest that this is true of the embryos cultured in conditioned medium.

In conclusion, glucose concentrations are reduced and lactate concentrations are increased by both oviductal cell co-culture or conditioning on oviductal cell monolayers. However, the glucose concentration is lower, and the lactate concentration is higher, in oviductal cell co-culture than in medium conditioned by oviductal cells. Development is delayed, and there are fewer cells in the blastocysts in embryos cultured in conditioned medium compared with those of co-cultured embryos. Glucose metabolism is greater in cattle embryos cultured in conditioned medium than in co-cultured embryos, suggesting that the activity of enzymes involved in glucose transport or metabolism in early cattle embryos is affected by the culture conditions. These observations suggest that the higher rate of glucose metabolism induced by culture in conditioned medium is unfavourable for subsequent development. However, further investigation is necessary to determine the specific mechanism(s) responsible for the effect on the glycolytic activity of cattle embryos, and whether a high rate of glucose metabolism leads to delayed development and fewer cells or, alternatively, that the observations have a common cause.

The authors thank F. Gandolfi, A. Massip and I. Donnay for their useful suggestions on the manuscript. Financial support was provided by the Commissariat Général aux Relations Internationales de la Communauté Française de Belgique pour l'accord culturel BelgiqueCanada, the Natural Science and Engineering Research Council of Canada, the CEE Biotechnology program (DG XII contract BIO2CT92-0067), and Semex Canada. Support for B. Grisart was provided by l'Institut pour l'encouragement de la Recherche Scientifique dans l'Industrie et l'Agriculture.

\section{References}

Bavister BD (1992) Co-culture for embryo development: is it really necessary Human Reproduction 7 1339-1341

Bavister BD (1995) Culture of preimplantation embryos: facts and artifacts Human Reproduction Update 1 91-148

Chatot CL, Ziomek CA, Bavister BD, Lewis JL and Torres I (1989) An improved culture medium supports development of random-bred 1-cell mouse embryos in vitro Journal of Reproduction and Fertility $\mathbf{8 6} 679-688$

Ellington JE, Carney EW, Farrell PB, Simkin ME and Foote RH (1990) Bovine 1-2-cell embryo development using a simple medium in three oviduct epithelial cell co-culture systems Biology of Reproduction 43 97-104

Erbach GT, Lawitts JA, Papaioannou VE and Biggers JD (1994) Differential growth of the mouse preimplantation embryo in chemically defined media Biology of Reproduction 50 1027-1033

Eyestone WH and First NL (1989) Co-culture of early cattle embryos to the blastocyst stage with oviductal tissue or in conditioned medium Journal of Reproduction and Fertility 85 715-720 
First NL and Parrish JJ (1987) In vitro fertilization of ruminants journal of Reproduction and Fertility Supplement 34 15 I-165

Fukui $\mathrm{Y}$ and Ono $\mathrm{H}$ (1988) In vitro development to blastocyst of in vitro matured and fertilised bovine oocytes Veterinary Record 122282

Gandolfi F (1994) Autocrine, paracrine and environmental factors influencing embryonic development from zygote to blastocyst Theriogenology 41 95-100

Gandolfi F and Moor RM (1987) Stimulation of early development in the sheep by co-culture with oviduct epithelial cells Journal of Reproduction and Fertility $8123-28$

Gordon I and Lu KH (1990) Production of embryos in vitro and its impact on livestock production Theriogenology 33 77-87

Greve $T$ and Madison V (1991) In vitro fertilization in cattle: a review Reproduction Nutrition Development 31 147-157

Grisart B, Massip A and Dessy F (1994) Cinematographic analysis of bovine embryo development in serum-free oviduct-conditioned medium journal of Reproduction and Fertility 101 257-264

Johnson WH, Loskutoff NM, Plante $Y$ and Betteridge KJ (1995) The production of four identical calves by the separation of blastomeres from an in vitro derived four cell embryo Veterinary Record 137 15-16

Leese HJ (1991) Metabolism of the preimplantation mammalian embryo. In Oxford Reviews of Reproductive Biology pp 35-72 Ed. SR Milligan. Oxford University Press, Oxford

Loskutoff NM, Johnson WH and Betteridge KJ (1993) The developmental competence of bovine embryos with reduced cell numbers Theriogenology 39 95-107

McKiernan SH, Bavister BD and Tasca RJ (1991) Energy substrate requirements for in vitro development of hamster 1-cell and 2-cell embryos to the blastocyst stage Human Reproduction 6 64-75

Massip A, Mermillod P, Wils C and Dessy F (1993) Effects of dilution procedure and culture conditions after thawing on survival of frozen bovine blastocysts produced in vitro Journal of Reproduction and Fertility 97 65-69

Massip A, Mermillod P, Van Langendonckt A, Touzé JL and Dessy F (1995) Survival and viability of fresh and frozen-thawed in vitro bovine blastocysts Reproduction Nutrition and Development 35 3-10

Mermillod P, Mourmeaux IL, Wils C, Massip A and Dessy F (1992a) Proteinfree oviduct conditioned medium supports complete bovine embryo development Veterinary Record $\mathbf{1 3 0} 13$

Mermillod P, Wils C, Massip A and Dessy F (1992b) Collection of oocytes and production of blastocysts in vitro from individual, slaughtered cows Journal of Reproduction and Fertility 96 717-723

Mermillod P, Vansteenbrugge A, Wils C, Mourmeaux JL, Massip A and Dessy F (1993) Characterization of the embryotrophic activity of exogenous proteinfree oviduct-conditioned medium used in culture of cattle embryos Biology of Reproduction $49582-587$

Pursel VG, Wall RJ, Rexroad CE, Hammer RE and Brinster RL (1985) A rapid whole-mount staining procedure for nuclei of mammalian embryos Theriogenology $24687-700$

Rexroad CE and Powell AM (1988) Co-culture of ovine ova with oviductal cells in Medium 199 Journal of Animal Science 66 947-953

Rieger D and Guay P (1988) Measurement of the metabolism of energy substrates in individual bovine blastocysts journal of Reproduction and Fertility $83585-591$
Rieger D, Bruyas J-F, Lagneau D, Bézard J and Palmer E (1991) The effect of cryopreservation on the metabolic activity of day- 6.5 horse embryos Journal of Reproduction and Fertility Supplement 44 411-417

Rieger D, Loskutoff NM and Betteridge KJ (1992a) Developmentally related changes in the metabolism of glucose and glutamine by cattle embryos produced and co-cultured in vitro Journal of Reproduction and Fertility 95 585-595

Rieger D, Loskutoff NM and Betteridge KJ (1992b) Developmentally related changes in the uptake and metabolism of glucose, glutamine and pyruvate by cattle embryos produced in vitro Reproduction Fertility and Development 4 547-557

Rieger D, Pollard JW and Leibo SP (1993) The effect of cryopreservation on the metabolic activity of in vitro produced cattle blastocysts Cryobiology $\mathbf{3 0} 631$ (Abstract)

Rosenkrans CF, Zeng GQ, McNamara GT, Schoff PK and First NL (1993) Development of bovine embryos in vitro as affected by energy substrates Biology of Reproduction 49 459-462

Schultz GA and Heyner S (1993) Growth factors in preimplantation mammalian embryos. In Oxford Reviews of Reproductive Biology pp 43-82 Ed. SR Milligan. Oxford University Press, Oxford

Takahashi $\mathrm{Y}$ and First NL (1992) In vitro development of bovine one-cell embryos: influence of glucose, lactate, pyruvate, amino acids and vitamins Theriogenology $37963-978$

Tervit HR, Whittingham DG and Rowson LEA (1972) Successful culture in vitro of sheep and cattle ova Journal of Reproduction and Fertilify 30 493-497

Thibault C (1966) La culture in vitro de l'oeuf de vache Annale de Biologie Animale, Biochimie et Biophysique 6 159-164

Thompson JG, Simpson AC, Pugh PA and Tervit HR (1992) Requirement for glucose during in vifro culture of sheep preimplantation embryos Molecular Reproduction and Development 31 253-257

Thompson JG, Bell ACS, Pugh PA and Tervit HR (1993) Metabolism of pyruvate by pre-elongation sheep embryos and effect of pyruvate and lactate concentrations during culture in vitro Reproduction Fertility and Development 5 $417-423$

Tiffin G, Rieger D, Betteridge KJ, Yadav BR and King WA (1991) Glucose and glutamine metabolism in pre-attachment cattle embryos in relation to sex and stage of development journal of Reproduction and Fertility 93 125-132

Trounson A, Pushett D, MacLellan LJ, Lewis I and Gardner DK (1994) Current status of IVM/IVF and embryo culture in humans and farm animals Theriogenology 41 57-66

Xu KP, Hill B and Betteridge KJ (1992a) Application of in vitro fertilisation techniques to obtain calves from valuable cows after slaughter Veterinary Record 130 204-206

Xu KP, Yadav BR, Rorie RW, Plante L, Betteridge KJ and King WA (1992b) Development and viability of bovine embryos derived from oocytes matured and fertilized in vitro and co-cultured with bovine oviducal epithelial cells Journal of Reproduction and Fertility 94 33-43

Yadav BR, King WA and Betteridge KJ (1993) Relationships between the completion of first cleavage and the chromosomal complement, sex, and developmental rates of bovine embryos generated in vitro Molecular Reproduction and Development 36 434-439 